\title{
COMPARISON OF FAMILY AND COMMUNITY CONTACTS OF MENTALLY SUBNORMAL ADULTS IN HOSPITAL AND IN LOCAL AUTHORITY HOSTELS
}

\author{
BY \\ AlisON C. CAMPBELL, M.A. (Sydney), Ph.D. (Edin.) \\ Department of Social and Preventive Medicine, University of Manchester
}

One argument in favour of community care for the mentally disordered is that in the community the person can maintain his contacts with family and friends. Hospitals for the mentally disordered in England and Wales tend to be geographically remote. This makes personal contacts with people outside the hospital difficult and fosters social isolation. Since the passing of the Mental Health Act, 1959 , numbers of mentally disordered patients have been discharged from hospitals to the community. For people without a home, or with homes that are unable or unwilling to have them back, local authorities are increasingly providing hostels. Lancashire County Council had by 1967 built fourteen such hostels for mentally disordered adults. 57 per cent. of residents to date have come from hospital. The object of the present study was to determine the extent to which residents who are transferred to hostels from hospital participate in contacts with family, friends, and the local community, i.e. whether mentally disordered adults transferred to hostels from hospital are any less isolated socially than comparable mentally disordered patients who remain in hospital.

\section{The Subjects}

The study is limited to the mentally subnormal. At the beginning of 1967 the residents in the Lancashire County hostels included 22 mentally subnormal men and fifteen mentally subnormal women from one of the main mental subnormality hospitals serving Lancashire County. These 37 residents were being used as an experimental group in a comparative study of the skills and abilities of mentally subnormal adults in hostels and hospital, and a control group of 37 matched subjects had been set up in the hospital from which the experimental group had come. These two groups, being readily available, were used also for the present study. The control group consists of subjects who, while suitable for local authority hostels, come from areas where hostels have not as yet been provided. Experimental and control subjects were matched for sex, age, grade of subnormality, and length of continuous institutionalization up to the time of the study. Relevant data are set out in Table I.

\section{TABLE I}

MEAN AGE, WAIS VERBAL I.Q., AND LENGTH OF CONTINUOUS INSTITUTIONALIZATION FOR 37 MATCHED PAIRS OF SUBNORMAL ADULTS IN HOSPITAL AND IN LOCAL AUTHORITY HOSTELS

\begin{tabular}{c|c|c|c|c}
\hline Group & $\begin{array}{c}\text { Number } \\
\text { of } \\
\text { Subjects }\end{array}$ & $\begin{array}{c}\text { Mean } \\
\text { Age } \\
\text { (yrs) }\end{array}$ & $\begin{array}{c}\text { Mean } \\
\text { WAIS } \\
\text { Verbal } \\
\text { I.Q.* }\end{array}$ & $\begin{array}{c}\text { Mean Length } \\
\text { of Continuous } \\
\text { Institutionalization } \\
\text { (mths) }\end{array}$ \\
\hline $\begin{array}{c}\text { Experimental } \\
\text { (hostel) }\end{array}$ & 37 & $\begin{array}{c}38 \cdot 4 \\
(\text { SD 12.8) }\end{array}$ & $\begin{array}{c}55 \cdot 0 \\
(\text { SD 7.0) }\end{array}$ & $\begin{array}{c}241 \cdot 4 \dagger \\
\text { (SD 133.8) }\end{array}$ \\
$\begin{array}{c}\text { Control } \\
\text { (hospital) }\end{array}$ & 37 & $\begin{array}{c}38 \cdot 4 \\
(\text { SD 12.9) }\end{array}$ & $\begin{array}{c}55 \cdot 2 \\
(\text { SD 7.0) }\end{array}$ & $\begin{array}{c}244 \cdot 6 \\
\text { (SD 135.3) }\end{array}$ \\
\hline
\end{tabular}

* Based on a sample size of 33 .

Four subjects in the experimental group failed to score on the WAIS, and four control subjects accordingly also fall below the minimum score level.

t Includes time in hospital before transfer to hostel plus time in hostel itself.

The groups were also matched with respect to civil state (all single), relationship to next of kin, family attitude to one's well-being, and family attitude to one's staying in a residential institution (hostel or hospital) all one's life. Relevant data are set out in Tables II and III. Family attitudes were judged from subjective ratings made by hostel wardens, ward sisters, or charge nurses, as appropriate.

The one variable relevant to contact with family and friends on which the experimental and control groups were found significantly to differ was the distance of next of kin from the subject's present place of residence (see Table IV). The hostel group live significantly closer than the hospital group to their next of kin $(P<0.001)$. This is what would be 
TABLE II

DISTRIBUTION OF NEXT OF KIN OF EXPERIMENTAL (HOSTEL) AND CONTROL (HOSPITAL) SUBJECTS IN TERMS OF RELATIONSHIP TO SUBJECT.

\begin{tabular}{l|c|c}
\hline $\begin{array}{c}\text { Relationship to } \\
\text { Subject of Next of Kin }\end{array}$ & $\begin{array}{c}\text { Experimental } \\
\text { Group }\end{array}$ & Control Group \\
\hline Parent & 19 & 22 \\
Sibling & 12 & 10 \\
Other & 6 & 2 \\
No known relatives & - & 3 \\
\hline \multicolumn{1}{c}{ Total } & 37 & 37 \\
\hline
\end{tabular}

TABLE III

FAMILY ATTITUDES TO EXPERIMENTAL (HOSTEL) AND CONTROL (HOSPITAL) SUBJECTS AS RATED BY HOSTEL AND HOSPITAL STAFF

\begin{tabular}{c|c|c}
\hline Family Attitude & $\begin{array}{c}\text { Experimental } \\
\text { Group }\end{array}$ & $\begin{array}{c}\text { Control } \\
\text { Group }\end{array}$ \\
\cline { 2 - 3 } $\begin{array}{c}\text { Definitely interested in subject's } \\
\text { well being }\end{array}$ & 11 & 11 \\
$\begin{array}{c}\text { Not particularly interested in } \\
\text { subject's well being } \\
\begin{array}{c}\text { Definitely not interested in sub- } \\
\text { ject's well being }\end{array}\end{array}$ & 16 & 14 \\
\hline Total & 37 & $34^{*}$ \\
\hline $\begin{array}{c}\text { Happy for subject to stay in } \\
\text { hostel/hospital indefinitely } \\
\text { Not happy for subject to stay in } \\
\text { hostel/hospital indefinitely }\end{array}$ & 35 & 33 \\
\hline Total & 37 & $34^{*}$ \\
\hline
\end{tabular}

* Three patients with no known relatives not included.

expected, as it is County policy to return patients to their own home area wherever possible. The hostel group, however, when in hospital, had been just as isolated geographically from kith and kin as the control group $(\mathrm{P}>0.05)$. Nor is there reason to doubt that the hostel group, when in hospital, were just as isolated as the control group socially. This assumption is supported by the fact that the families of the

\section{TABLE IV}

DISTANCE OF NEXT OF KIN FROM SUBJECT'S PRESENT PLACE OF RESIDENCE AND (FOR THE EXPERIMENTAL GROUP) FROM SUBJECT'S PREVIOUS PLACE OF RESIDENCE

\begin{tabular}{|c|c|c|c|}
\hline \multirow{2}{*}{$\begin{array}{c}\text { Distance } \\
\text { (miles) }\end{array}$} & \multicolumn{2}{|c|}{ Experimental Group } & \multirow{2}{*}{$\begin{array}{l}\text { Control Group } \\
\text { (in hospital) }\end{array}$} \\
\hline & In hostel & When in hospital & \\
\hline$<15$ & 30 & 5 & 8 \\
\hline $15-30$ & 1 & 22 & 15 \\
\hline$>30$ & 5 & 9 & 11 \\
\hline Not known & 1 & 1 & 3 \\
\hline Total & 37 & 37 & 37 \\
\hline
\end{tabular}

hostel residents were judged to be no more interested in their well-being than were the families of the members of the control group in the control subjects' well-being. Experimental and control groups being $?$ matched with respect to all major variables poten- $\overrightarrow{\bar{F}}$ tially relevant to contact with family or friends, except for distance of next of kin from the subject's present place of residence, it is permissible to ask whether the significant decrease in geographical isolation achieved by transferring the experimental group from hospital to hostels has entailed a corresponding o decrease in social isolation.

\section{CONTACT WITH Families}

Contact with families is shown in Table V. $\frac{\mathscr{\sigma}}{\circ}$ "Contact" refers to visiting or being visited by $\stackrel{\rho}{\mathcal{S}}$ family members. Information on contact with i families was supplied by hostel and hospital staff, $\underset{\omega}{\omega}$ with corroboration from the subjects themselves $\vec{\nabla}$ wherever possible. Significantly more hostel resi- o dents than hospital patients had personal contacts 으 with family members, and their contacts were significantly more frequent $(\mathrm{P}<0.001$ in each case). $c$ The social isolation from kin of subjects lacking in personal contacts with family members was little $\vec{\bullet}$ alleviated by impersonal contact through the posద $\infty$ Two of the nine hostel residents who had no personal contact with family members received a⿳⺈ occasional letter from a relative, usually at birthdays or Christmas. Six of the nineteen hospital patients who had no personal contact with family members received an occasional letter in the same way.

\section{TABLE V}

CONTACT BETWEEN EXPERIMENTAL (HOSTEL) SUBJECTS AND CONTROL (HOSPITAL) SUBJECTS AND THEIR FAMILIES AND FREQUENCY OF SUCH CONTACTS

\begin{tabular}{l|c|c}
\hline Contacts with Family & $\begin{array}{c}\text { Experimental } \\
\text { Group }\end{array}$ & Control Group \\
\hline Yes & 28 & 15 \\
No & 9 & 19 \\
\hline Total & 37 & $34^{*}$ \\
\hline \multicolumn{2}{l}{} \\
\hline \multicolumn{2}{l}{$\chi^{2}=16 \cdot 15 ;$ d.f. $=1 ; \mathrm{P}<0.001}$.
\end{tabular}

\begin{tabular}{l|c|c}
\hline Frequency of Contacts & $\begin{array}{c}\text { Experimental } \\
\text { Group }\end{array}$ & Control Group \\
\hline At least once a week & 13 & 1 \\
$\begin{array}{l}\text { Between a week and a } \\
\text { month }\end{array}$ & 12 & 3 \\
Less than once a month & 3 & 11 \\
None & 9 & 19 \\
\hline Total & 37 & $34^{*}$ \\
\hline
\end{tabular}

$\chi^{2}=24 \cdot 35 ;$ d.f. $=3 ; P<0 \cdot 001$

* Three patients with no known relatives not included. 
The nature of the contacts between subjects and their families is set out in Table VI. Significantly more hostel residents than hospital patients go to visit family members $(P<0 \cdot 01)$. The difference between the groups in the number of subjects visited by family members is not however significant. The 22 hostel residents who go to visit their families rarely stay more than a few hours. Only six ever stay overnight. For hospital patients the pattern is otherwise. For seven of the eight patients who go to visit their families, the visits take the form of an annual holiday of a week or more. The family of the eighth patient live only 10 miles from the hospital (i.e. relatively close) and this patient visits his family one afternoon a month.

TABLE VI

NATURE OF CONTACTS BETWEEN EXPERIMENTAL (HOSTEL) AND CONTROL (HOSPITAL) GROUPS AND THEIR FAMILIES

\begin{tabular}{|c|c|c|c|}
\hline Group .. & . $\quad \ldots$ & Experimental & Control \\
\hline $\begin{array}{l}\text { Visits } \\
\text { to } \\
\text { Family }\end{array}$ & $\begin{array}{l}\text { Yes } \\
\text { No }\end{array}$ & $\begin{array}{l}22 \\
15\end{array}$ & $\begin{array}{r}8 \\
26\end{array}$ \\
\hline Total & & 37 & 34 \\
\hline
\end{tabular}

$\chi^{2}=8 \cdot 26 ;$ d.f. $=1 ; \mathrm{P}<0.01$.

\begin{tabular}{|c|c|c|c|}
\hline Group .. & . & Experimental & Control \\
\hline \multirow{2}{*}{$\begin{array}{c}\text { Visited } \\
\text { by } \\
\text { Family }\end{array}$} & Yes & 19 & 15 \\
\hline & No & 18 & 19 \\
\hline \multicolumn{2}{|l|}{ Total } & 37 & 34 \\
\hline
\end{tabular}

\section{Contact With Friends}

Data on contact with outside friends, derived as for contact with families, are set out in Table VII. The difference between groups in the number of subjects in touch with outside friends and in the frequency of such contacts just fails to reach significance at the 0.05 level. The most striking fact, however, about Table VII is that the great majority of subjects in both the experimental and the control groups had no personal contacts with any outside friends at all. Nor did many subjects have impersonal contacts with outside friends by letter. Only two of the 34 control subjects without personal contacts with friends received an occasional letter from people outside the hospital. Nine of the 28 experimental subjects without personal contacts with outside friends received an occasional letter from people outside the hostel. In every case these friends were patients in the hospital from which the experimental subjects had come, not people from the community at large.

TABLE VII

CONTACT BETWEEN EXPERIMENTAL (HOSTEL) SUBJECTS AND CONTROL (HOSPITAL) SUBJECTS AND OUTSIDE FRIENDS AND FREQUENCY OF SUCH CONTACTS

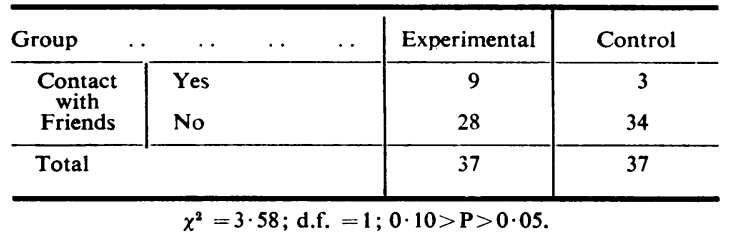

\begin{tabular}{|c|c|c|c|}
\hline Group & .. & Experimental & Control \\
\hline \multirow{4}{*}{$\begin{array}{c}\text { Frequency } \\
\text { of } \\
\text { Contact }\end{array}$} & $\begin{array}{l}\text { At least once a } \\
\text { week }\end{array}$ & 6 & - \\
\hline & & - & 1 \\
\hline & & 3 & 2 \\
\hline & None & 28 & 34 \\
\hline \multicolumn{2}{|l|}{ Total } & 37 & 37 \\
\hline
\end{tabular}

Subjects with No Personal Contacts

OUtSIDE THE HOSTEl OR HOSPITAL

Nine (24 per cent.) of the hostel group and nineteen (51 per cent.) of the hospital group had no outside contacts of a specifically personal nature, i.e. they never visited relatives, never visited friends, were never visited by relatives, and were never visited by friends. The difference between the groups in this respect is significant $(\mathrm{P}<0 \cdot 05)$.

\section{Contact With the Community at LARge}

Contact with the community at large here refers to casual and informal contacts with comparative or total strangers in the course of daily living. Such contacts necessarily depend on the freedom of movement that the person enjoys. The number of experimental and control subjects allowed out alone, with other residents or patients, or with staff only, is shown in Table VIII. The difference between the groups is highly significant $(\mathrm{P}<0 \cdot 001)$. Hostel residents are allowed out of the hostel grounds as of right, and all 37 of the hostel group take advantage of this. All 37 go out of the grounds at least once a week, and 34 go out both during the week and at weekends. The other three go out at weekends only. The hospital subjects are allowed out of the grounds unsupervised only if they are on parole. The 23 hospital subjects who were on parole typically went out of the hospital grounds in groups 
TABLE VIII

NUMBER OF EXPERIMENTAL (HOSTEL) AND CONTROL (HOSPITAL) SUBJECTS ALLOWED OUT ALONE OR WITH OTHER RESIDENTS OR PATIENTS OR WITH STAFF ONLY

\begin{tabular}{|c|c|c|c|}
\hline Group . . & . & Experimental & Control \\
\hline $\begin{array}{c}\text { Allowed } \\
\text { out }\end{array}$ & $\begin{array}{l}\text { Alone } \\
\begin{array}{l}\text { With other resi- } \\
\text { dents or patients }\end{array} \\
\text { With staff only }\end{array}$ & $\begin{array}{l}27 \\
10 \\
-\end{array}$ & $\left.\begin{array}{l}1 \\
22\end{array}\right\} \begin{array}{l}\text { On parole } \\
14 \begin{array}{l}\text { Not on } \\
\text { parole }\end{array}\end{array}$ \\
\hline Total & & 37 & 37 \\
\hline
\end{tabular}

$\chi^{2}=42.64 ;$ d.f. $=2 ; \mathrm{P}<0.001$.

of three to a nearby town for a half-day at a time. The frequency of such outings is shown in Table IX.

TABLE IX

APPROXIMATE FREQUENCY WITH WHICH CONTROL (HOSPITAL) SUBJECTS GO OUT OF HOSPITAL GROUNDS, OTHER THAN ON ORGANIZED TRIPS OR HOLIDAYS

\begin{tabular}{l|c}
\hline Interval between Outings & Number of Subjects \\
\hline 2 wks & 1 \\
4 wks & $8^{*}$ \\
6 wks & 8 \\
2 mths & 1 \\
4 mths & 4 \\
6 mths & 1 \\
Not applicable & 14 \\
(not on parole) & 37 \\
\hline Total & \\
\hline
\end{tabular}

* Two of these patients were allowed out from Easter to October only. The charge nurse on their ward did not consider it advisable for patients to go out of the grounds during the winter months.

In contrast to the hostel residents, not one of the hospital patients goes out of the grounds as often as once a week. The frequency with which parole patients go out of the hospital grounds depends on hospital policy and on the patient's inclination and financial state. Not all parole patients have sufficient money, when the time is at hand, for the half-day trip to a nearby town. The comparative lack of contact of the hospital group with the community at large is not due to their being any less capable than the hostel group of mingling with the general population. This is evident from the fact that the two groups are matched not only for the characteristics set out in Tables I to III but also with respect to the number of subjects who can and do use public transport unaided, as shown in Table X.

\section{TABLE X}

NUMBER OF EXPERIMENTAL (HOSTEL) AND CONTROL (HOSPITAL) SUBJECTS WHO USE PUBLIC TRANSPORT WITHOUT HELP OR SUPERVISION

\begin{tabular}{|c|c|c|c|}
\hline Group & . . & Experimental & Control \\
\hline $\begin{array}{c}\text { Uses public } \\
\text { transport without } \\
\text { help or supervision }\end{array}$ & $\begin{array}{l}\text { Yes } \\
\text { No }\end{array}$ & $\begin{array}{l}20 \\
17\end{array}$ & $\begin{array}{l}23^{*} \\
14\end{array}$ \\
\hline \multicolumn{2}{|l|}{ Total } & 37 & 37 \\
\hline
\end{tabular}

$\chi^{2}=0 \cdot 50$; d.f. $=1 ; P>0 \cdot 30$.

*i.e. all control group patients on parole.

\section{Discussion}

The finding that significantly more hostel residents than hospital patients visit family members is attributable in the first place to factors of geography (the hostel residents live closer to their families) and secondly to differences in the organizational régimes of the two types of institution (outside visiting being relatively unrestricted for the hostel residents). The mentally disordered adults dealt with here are known to desire contact with home and family (Campbell, 1968), and given the opportunity they earnestly seek their families out. That the hostel group were no more frequently visited by their families than were the hospital group is probably due, at least in part, to the fact that the families of mentally disordered persons do not always desire: contact with them. There is also the fact that the rooms in the Lancashire hostels are so arranged that there is little opportunity for visitors to be entertained in any privacy. Hence, even if a resident's family welcomes contact with him, it is generally more convenient for the resident to visit his family than for members of his family to visit him.

With regard to contact with outside friends, mentally subnormal adults discharged from hospital to their area of origin seem not to re-establish contacts with erstwhile friends or acquaintances. Possibly they had no friends or acquaintances to start with. Nor do mentally subnormal adults discharged from hospital to hostels seem to establish new friendships. Possibly they are not interested or do not know how. All the hostel group had had time to establish or re-establish outside friendships, having been in the hostels for at least 7 months. That 76 per cent. of the hostel group had no friends outside the hostel has disturbing implications. As hostel residents grow older their contacts with family will tend to decrease through the death of relatives, particularly parents. Lacking contacts with friends, an increasing number of residents will accordingly come to have no personal contacts outside the hostel at all. For the inmates of a hostel, 
hospital, or any other residential institution to have no contacts with persons outside the institution is a contributory factor to the development of institutional neurosis (Barton, 1959). Residents transferred to the hostels from hospital tend already to show signs of institutionalization, and failure on the part of the hostels to foster contact between these residents and persons outside the hostel does nothing to alleviate the situation.

With regard to contacts with the community at large, the finding that the hostel group had significantly more contact with chance acquaintances and strangers would again seem to be due to the geographical location of the hospital and the way in which it is run. It is certainly not due to the members of the hospital group being any less capable of mingling with the general population or of finding their way around the environment.

\section{Summary AND CONClusions}

A study was undertaken to determine whether mentally subnormal adults transferred from a mental subnormality hospital to local authority hostels are less socially isolated from family, friends, and the local community than are comparable mentally subnormal adults still in hospital. An experimental group was taken of $\mathbf{3 7}$ mentally subnormal residents in the Lancashire County hostels for mentally subnormal adults. These 37 residents (22 men and fifteen women) had all come from one of the main mental subnormality hospitals serving Lancashire County. A control group of $\mathbf{3 7}$ mentally subnormal patients was set up in the hospital from which the experimental group had come. Experimental and control subjects were matched for sex, age, grade of subnormality, and length of continuous institutionalization up to the time of the study. The two groups proved also to be matched for civil state (all single), relationship to next of kin, family attitude towards one's well-being and towards one's staying indefinitely in a residential institution, and distance of next of kin from the hospital. The one variable on which the groups significantly differed was-the distance of next of kin from the subject's present place of residence, i.e. hostel as opposed to hospital. The hostel residents live significantly closer to their families and so have more ready access to them. The hostel residents took advantage of this and were significantly less isolated from family members not only geographically but also socially.

The difference between hostel residents and hospital patients in the number and frequency of contacts with outside friends just failed to reach significance at the 0.05 level. However, the great majority of subjects in both the hostel and the hospital groups had no outside friends at all. Some people with no outside friends had no contacts with family either, i.e. they had no social contacts of a personal nature with anyone outside the hostel or hospital. Significantly more of the hospital group were completely lacking in such contacts.

With regard to contact with the community at large the geographical isolation and the organizational régime of the hospital act against the establishment or maintenance of social contacts between patients and the outside world. The hostel residents on the other hand regularly engage in a variety of informal contacts with chance acquaintances and comparative or total strangers. Hence the experimental group of mentally subnormal adults in the Lancashire County hostels, even those who had no specific social contacts with people outside the hostel, were none the less significantly less socially isolated than the control group of comparable mentally subnormal adults in hospital. On the argument that social isolation is in itself detrimental to mental health, the findings of the present study are a vindication of the policy of community care.

The research reported herein is sponsored by the Ministry of Health and was initiated by $\mathrm{Dr}$ M. W. Susser, formerly of the University of Manchester, in conjunction with Dr Joyce E. Leeson. My thanks are due to Dr S. C. Gawne, Lancashire County Medical Officer of Health, to the staff and residents of the Lancashire County hostels and to the staff and patients of the mental subnormality hospital for their willing co-operation in the research.

\section{REFERENCES}

Barton, R. (1959). "Institutional Neurosis". Wright, Bristol.

Campbell, A. C. (1968). Brit. J. prev. soc. Med., 22, 94 (Attitudes of mentally disordered adults to community care). 